\title{
PENGARUH PEMBERIAN TEPUNG LIMBAH LABU KUNING (Cucurbita moschata) DALAM RANSUM TERHADAP PERSENTASE KARKAS, POTONGAN KOMERSIL DAN LEMAK ABDOMINALPADAAYAM PEDAGING
}

\author{
Mianty. C. Pakasi, J. S. Mandey*, Y. H. S. Kowel, M. N. Regar
}

Fakultas Peternakan Universitas Sam Ratulangi. Manado, 95115

\begin{abstract}
ABSTRAK
Penelitian ini bertujuan untuk mengetahui pengaruh pemberian limbah labu kuning (Cucurbita moschata)sebagai pengganti sebagian ransum terhadap persentase karkas, persentase potongan komersil karkas (dada, paha, sayap) dan lemak abdominal pada ayam pedaging.Penelitian menggunakan 100 ekor ayam pedaging unsexed, strain Cobb umur 1 hari.Rancangan yang digunakan adalah Rancangan Acak Lengkap (RAL) yang terdiri dari 4 perlakuan dan 5 ulangan. Uji lanjut yang digunakan adalah Beda Nyata Jujur (BNJ). Susunan perlakuan sebagai berikut: $\mathrm{R}_{0}=$ Ransum Basal (RB) $100 \%+0 \%$ Tepung Limbah Labu Kuning(TLLK) $; \mathrm{R}_{1}=\mathrm{RB} \quad 95 \%$ $+5 \% \mathrm{TLLK} ; \mathrm{R}_{2}=\mathrm{RB} 90 \%+10 \% \mathrm{TLLK} ; \mathrm{R}_{3}=$ RB $\quad 85 \%+15 \%$ TLLK.Hasil analisis menunjukkanbahwa bobot karkas dan persentase karkas pada perlakuan $R_{0}, R_{1}$, $R_{2}$, nyata lebih tinggi dibanding dengan perlakuan $R_{3}$, namun antara perlakuan $R_{0}$, $\mathrm{R}_{1}, \quad \mathrm{R}_{2}$ berbedatidak nyata.Potongan komersil bagian dada kanan pada perlakuan $R_{1}, R_{2}, R_{3}$,nyata lebih tinggi dari perlakuan $R_{0}$, tetapi antara perlakuan $R_{1}$, $\mathrm{R}_{2}, \quad \mathrm{R}_{3}$ berbeda tidak nyata, sedangkan padabagian dada kiri menunjukkan bahwa perlakuan $R_{0}, R_{2}, R_{3}$ nyata lebih dari perla
\end{abstract}

\footnotetext{
*Korespondensi (Corresponding author): Email: jetsm_fapet@yahoo.co.id
}

kuan $\mathrm{R}_{0}$, tetapi antara perlakuan $\mathrm{R}_{1}, \mathrm{R}_{2}$, $\mathrm{R}_{3}$ berbeda tidak nyata, sedangkan padabagian dada kiri menunjukkan bahwaperlakuan $\mathrm{R}_{0}, \mathrm{R}_{2}, \quad \mathrm{R}_{3}$ nyatalebih tinggi dibanding perlakuan $R_{1}$, namun antaraperlakuan $R_{0}, R_{2}, R_{3}$ berbeda tidak nyata.Potongan paha dan sayap, dan persentase lemak abdominal menunjukkan perbedaan yang tidak nyata. Berdasarkan hasil penelitian dapat disimpulkan bahwa pemberian tepung limbah labu kuning sebanyak $15 \%$ dalam ransum ayam pedaging memberikan pengaruh yang baik terhadap pertumbuhan bobot badan, persentase karkas dan sebagian persentase potongan komersil karkas ayam pedaging.

Kata kunci:Ayam pedaging, Labu kuning, Karkas, Lemak abdominal, Potongan komersil karkas.

\section{ABSTRACT}

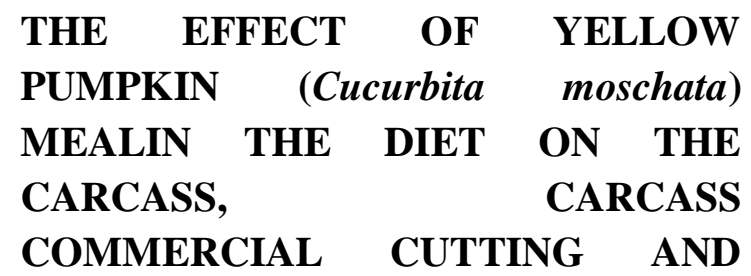

ABDOMINAL FAT OF BROILER CHICKENS. This study aims to determine the effect of pumpkin (Cucurbita moschata) waste in the diet on carcass percentage, commercial cutting of carcass (breasts, thighs, wings) and abdominal fat in broilers. The study used 100 unsexed D.O.C. of broilers, strain Cobb. The experiment used a completely randomized design (CRD) consisting of 4 
treatments and 5 replications. The followup test used was Honest Real Difference $(\mathrm{BNJ})$. The treatment arrangements are as follows: R0 $=$ Basal Diet (BD) $100 \%+0 \%$ Yellow Pumpkin Meal (YPM); R1 = BD $95 \%+5 \%$ YPM; R2 = BD 90\% + 10\% YPM; R3 = BD 85\% + 15\% YPM. The results showed that carcass weight and carcass percentage in treatment R0, R1, R2 were significantly higher than treatment $\mathrm{R} 3$, but between treatments $\mathrm{R} 0, \mathrm{R} 1, \mathrm{R} 2$ were not significantly different. The commercial section of the right chest of treatment R1, R2, R3, was significantly higher than the $\mathrm{R} 0$ treatment, but between treatments R1, R2, R3 were not significantly different, while on the left chest showed that treatments R0, R2, R3 were significantly higher than R1, however, between treatments R0, R2, R3 were not significantly different. Thigh and wing sections, and abdominal fat percentage showed no significant differences. Based on the results, it can be concluded that $15 \%$ pumpkin waste mealin broiler diet has a good effect on body weight growth, carcass percentage and part of the commercial cutting percentage of broiler carcass.

Key words: Abdominal fat, Broilers, Carcass, Commercial cutting, Pumpkin.

\section{PENDAHULUAN}

Karkas merupakan hasil utama yang diharapkan dalam usaha peternakan ayam pedaging. Penimbunan lemak yang terlalu banyak pada abdomen ternak ayam pedaging dapat menurunkan kualitas karkas yang dihasilkan. Penggunaan bahan pakan yang memiliki kandungan serat kasar tinggi merupakan alternatif mengurangi penimbunan lemak.

Serat kasar yang tinggi menyebabkan unggas merasa kenyang, sehingga dapat menurunkan konsumsi pakan karena serat kasar bersifat voluminous yang akan mempengaruhi kualitas karkas dan lemak abdominalnya. Mandey, et al. (2017) melaporkan bahwa pakan yang mengandung $3100 \mathrm{Kcal} / \mathrm{kg}$ ME dan $11 \%$ serat kasar menurunkan konsumsi pakan, persentase lemak abdominal, dan LDL-kolesterol darah, tetapi tidak mempengaruhi berat badan akhir dan nilai HDL-kolesterol darah serta memiliki nilai persentase karkas yang baik.

Labu kuning (Cucurbita moschata) merupakan alternatif sumber serat kasar.Komposisi kandungan zat gizi limbah labu kuning per 100 gram antara lain:protein $23,14 \%$, lemak $14,59 \%$, serat kasar $17,48 \%$, kalsium $0,76 \%$, fosfor 0,75\% (Komalig et al, 2016). Menurut data terakhir(BPS, 2014), produksi labu kuning pada tahun 2014 di Indonesia sebesar 523.063 ton.

Beberapa penulis melaporkan penggunaan biji labu kuning 10 dan 15 $\mathrm{g} / \mathrm{kg}$ dalam ransum meningkatkan berat karkas, menurunkan kolesterol plasma dan trigliserida, tidak mempengaruhi berat badan, edible meat, dada, sayap, serta total protein daging puyuh (Abbas et al., 2017). 
Gaafar et al. (2014) mendapatkan peningkatan berat badan kelinci yang diberi makan minyak biji labu kuning 5 $\mathrm{g} / \mathrm{kg}$ ransum.Penggunaankombinasi daun kelor (Moringa oleifera,Lam), labukuning (Cucurbita moschata,Durch)danminyak kelapasebagai pengganti jagungdengan kombinasi perlakuan mulai dari level $5 \%, 10 \%$ dan $15 \%$ dalam pakan cukupbaik pengaruhnya terhadap persentase daging, tulangdan karkas (Bona et al., 2015).Penambahan 0, 33, 66 dan 100 g/kg tepung biji labu dalam diet ayam pedaging, menggantikan sebagian tepung kedelai dan minyak sayur, meningkatkan bobot hidup dan edible portion. Lemak abdominal dan kadar serum lipid berbahaya menurun, sedangkan kadar serum lipid bermanfaat meningkat (Aguilar et al., 2011).

Nawirska-Olszanska, et al. (2013)melaporkan bahwa biji labu merupakan sumber protein dan lemak yang berharga.Minyak biji labu mengandung asam lemak seperti palmitat (C16: 0), stearic (C18: 0), oleic (C18: 1) dan linoleic (C18: 2), vitamin E dan A, nutrisi penting: seng, magnesium, fosfor, tembaga, kalium, niasin, asam folat, riboflavin tiamin dan protein berkualitas tinggi (Eleiwa et al., 2014). Bioaktif dari biji labu membantu mengurangi lemak abdominal dan kadar serum lipid berbahaya, meningkatkan kadar serum lipid bermanfaat. Penggunaan $100 \mathrm{~g} / \mathrm{kg}$ tepung linseed dan biji labu meningkatkan bobot hidup, edible portion dan asam lemak esensial dalam daging dada kalkun, tanpa mempengaruhi kualitas sensorik daging (Chiroque et al., 2018).

$$
\text { Labu memiliki manfaat dalam }
$$
kinerja produktif ternak ketika ditambahkan dalam ransum. Tingginya kandungan antioksidan dan asam lemak yang ada dalam buah dan biji, meningkatkan beberapa karakteristik daging, susu, atau telur (Valdez and Mella, 2019).Tepung biji labu adalah sumber lemak dan protein yang baikdan dapat menggantikan bungkil kedelai dalam diet ayam broiler hingga 20\% (Wafar et al., 2017).

Penelitian bertujuan untuk mengukur pengaruh penggunaan tepung limbah labu kuning sebagai pakan alternatif pengganti sebagian ransum ayam pedaging.

\section{MATERI DAN METODE PENELITIAN}

Ternak yang digunakan dalam penelitian ini adalah 100 ekor ayam pedaging unsexed, strain Cobb umur 1 hari.Kandang yang digunakan adalah kandang sistem battery terbuat dari kawat dengan ukuran $60 \times 45 \times 45 \mathrm{~cm}$ sebanyak 20 unit tiap unit kandang ditempatkan 5 ekor ayam. Ransum basal terdiri atas jagung $47 \%$, tepung kedelai $14 \%$, tepung ikan 14\%, bungkil kelapa 5,5\%, dedak 
halus $18 \%$, minyak $1 \%$, top mix $0,5 \%$. Dan tepung limbah labu kuning sebagai perlakuan menggantikan ransum basal dengan level 0, 5, 10, dan 15\%. Komposisi nutrien bahan pakan penyusun ransum dapat dilihat pada Tabel 1, dan komposisi nutrien dan energi metabolis pakan perlakuan dapat dilihat pada Tabel 2.

Penelitian

menggunakan

Rancangan Acak Lengkap (Steel and Torrie, 1994) yang terdiri dari 4 perlakuan dan 5 ulangan. Susunan perlakuan sebagai berikut:

$\mathrm{R}_{0}=$ Ransum Basal 100\% (Tanpa Tepung Limbah Labu Kuning)

$\mathrm{R}_{1}=$ Ransum Basal 95\% + Tepung Limbah

Labu Kuning 5\%

$\mathrm{R}_{2}=$ Ransum Basal 90\% + Tepung Limbah

Labu Kuning 10\%

$\mathrm{R}_{3}=$ Ransum Basal 85\% + Tepung Limbah

Labu Kuning 15\%

Tabel 1. Komposisi Nutrien Bahan Pakan Penyusun Ransum

\begin{tabular}{lcccccc}
\hline \multicolumn{1}{c}{ Bahan Makanan } & Protein & $\begin{array}{c}\text { Serat } \\
\text { Kasar }\end{array}$ & Lemak & Ca & P & EM \\
\hline \multicolumn{7}{c}{$\%$} \\
\hline Jagung* & 8,01 & 3,45 & 7,71 & 0,17 & 0,7 & 3821 \\
Tepung Kedelai* & 42,04 & 6,4 & 13,22 & 0,21 & 0,65 & 4804 \\
Tepung Ikan* & 63,6 & 0,5 & 9,3 & 5,81 & 3,23 & 2830 \\
Bungkil Kelapa* & 20,55 & 15,88 & 15,07 & 0,21 & 0,49 & 4966 \\
Dedak Halus* & 8,36 & 16,53 & 6,58 & 0,13 & 0,84 & 3419 \\
Minyak & - & - & 100 & - & - & 8812 \\
Top Mix & - & - & - & 5,38 & 1,44 & - \\
Tepung Limbah Labu & 23,14 & 17,48 & 14,59 & 0,76 & 0,75 & 3882,4 \\
Kuning** & & & & & \\
\hline Sumber: * Salombre, et al. (2018) & & & & &
\end{tabular}

Tabel 2. Komposisi Nutrien dan Energi Metabolis Pakan Perlakuan

\begin{tabular}{lcccc}
\hline \multirow{2}{*}{ Nutrien } & \multicolumn{3}{c}{ Perlakuan } \\
\cline { 2 - 5 } & R0 & R1 & R2 & R3 \\
\hline Protein (\%) & 21,19 & 21,29 & 21,39 & 21,48 \\
Serat Kasar $(\%)$ & 6,44 & 6,99 & 7,54 & 9,75 \\
Lemak (\%) & 9,79 & 10,03 & 10,27 & 11,23 \\
Ca (\%) & 0,98 & 0,97 & 0,96 & 0,95 \\
P (\%) & 1,06 & 1,04 & 1,03 & 1,01 \\
EM (Kcal/kg) & 3841,3 & 3843,4 & 3845,4 & 3847,5 \\
\hline
\end{tabular}

Keterangan: Dihitung berdasarkan Tabel 1. 


\section{Variabel yang Diukur}

\section{Bobot Karkas (g/ekor)}

Bobot karkas (g/ekor) dapat dihitung dengan menimbang tubuh ayam yang telah dipotong pada umur 35 dikurangi dengan darah, bulu, kepala, kaki, leher dan organ dalam.

\section{Persentase karkas (\%)}

Persentasi karkas dapat diukur dengan membandingkan bobot ayam tanpa bulu, darah, kepala, leher, kaki dan organ dalam (g) kecuali jantung, hati dan gizzard dengan bobot hidup (g) kemudian dikalikan $100 \%$.

Persentase bobot karkas

$=\frac{\text { Bobot karkas }(g)}{\text { Bobot hidup }(g)} \times 100 \%$

\section{Persentase Potongan Komersial}

(Paha, Sayap, dan Dada) (\%)

Potongan komersial karkas dinyatakan dalam bobot dan persentase terhadap bobot karkas. Setiap potongan ditimbang bobotnya kemudian dihitung rasio perbandingannya dalam persen karkas dari setiap perlakuan yang diberikan. Bagian-bagian karkas yang termasuk dalam potongan komersil adalah dada, sayap dan paha. Rumus yang digunakan untuk menghitung persentase setiap bagian karkas adalah sebagai berikut:
Bagian karkas $=\frac{\text { Bobot bagianb karkas }(g)}{\text { Bobot karkas }(g)} \times 100 \%$

4. Persentase lemak abdominal (\%)

Pengukuran bobot lemak abdomen dilakukan dengan cara menimbang lemak yang didapat dari lemak yang berada pada sekeliling gizzard dan lapisan yang menempel antara otot abdomen serta usus dan selanjutnya ditimbang. Persentase lemak abdomen diperoleh dengan membandingkan bobot lemak abdomen dengan bobot hidup dikalikan $100 \%$ (Witantra, 2011).

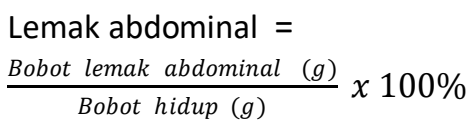

\section{HASIL DAN PEMBAHASAN}

Rataan bobot karkas, persentase karkas, potongan komersil karkas dan lemak abdominal ayam pedaging selama penelitian disajikan pada Tabel 3.

\section{Pengaruh Perlakuan Terhadap Bobot} Karkas

Rataan bobot karkas ayam pedaging dapat dilihat pada Tabel 3. Pada tabel tersebut terlihat bahwa bobot karkas tertinggi ada dalam perlakuan $\mathrm{R}_{1}(5 \%$ tepung limbah labu kuning)dan bobot karkas terendah ada dalam perlakuan $\mathrm{R}_{3}$ (15\% tepung limbah labu kuning). 
Tabel 3. Rataan Bobot Karkas, Bagian Komersil Karkas dan Lemak Abdominal pada Ayam Pedaging dari Masing-Masing Perlakuan.

\begin{tabular}{lcccc}
\hline \multirow{2}{*}{ Variabel } & \multicolumn{4}{c}{ Perlakuan } \\
\cline { 2 - 5 } & $\mathrm{R}_{0}$ & $\mathrm{R}_{1}$ & $\mathrm{R}_{2}$ & $\mathrm{R}_{3}$ \\
\hline Bobot karkas (gram) & $740,4^{\mathrm{a}}$ & $774,46^{\mathrm{a}}$ & $772,03^{\mathrm{a}}$ & $615,34^{\mathrm{b}}$ \\
\hline Persentase karkas (\%) & $69,1^{\mathrm{a}}$ & $67,33^{\mathrm{a}}$ & $67,17^{\mathrm{a}}$ & $64,79^{\mathrm{b}}$ \\
\hline Bagian Komersil & & & & \\
Karkas (\%) & & & & \\
$\quad$ - Paha kanan & 14,17 & 14,91 & 14,66 & 14,29 \\
- Paha kiri & 14,35 & 14,64 & 14,98 & 13,99 \\
- Sayap kanan & 5,66 & 5,86 & 6,16 & 6,15 \\
- Sayap kiri & 5,77 & 5,49 & 5,56 & 6,18 \\
- Dada kanan & $13,1^{\mathrm{b}}$ & $15,45^{\mathrm{a}}$ & $16,13^{\mathrm{a}}$ & $16,73^{\mathrm{a}}$ \\
$\quad$ - Dada kiri & $17,73^{\mathrm{a}}$ & $14,98^{\mathrm{b}}$ & $16,74^{\mathrm{a}}$ & $16,64^{\mathrm{a}}$ \\
\hline Persentase lemak & 1,7 & 1,68 & 2,07 & \multirow{2}{*}{1,35} \\
abdominal (\%) & & & & \\
\hline Keterganyyyy
\end{tabular}

Keterangan: Superskrip berbeda pada baris yang sama menunjukkan perbedaan yang nyata $(\mathrm{P}<0,05)$

Hasil analisis keragaman menunjukkan bahwa perlakuan pemberian tepung limbah labu kuning dalam ransum memberikan pengaruh berbeda sangat nyata $(\mathrm{P}<0,01)$ terhadap bobot karkas ayam pedaging. Berdasarkan uji lanjut beda nyata jujur (BNJ) menunjukkan bahwa perlakuan $\mathrm{R}_{0}, \mathrm{R}_{1}, \mathrm{R}_{2}$, nyata $(\mathrm{P}<0,01)$ lebih tinggi daripada $\mathrm{R}_{3}$, namun diantara $\mathrm{R}_{0}, \mathrm{R}_{1}$, $\mathrm{R}_{2}$ tidakberbeda nyata $(\mathrm{P}>0,01)$. Bobot karkas sangat dipengaruhi oleh bobot hidup yang besar diikuti oleh bobot karkas yang besar pula, dan sebaliknya.

Menurut Subekti,et al.(2013) bobot karkas yang dihasilkan dipengaruhi oleh beberapa faktor yaitu umur, jenis kelamin, bobot potong, besar dan konformasi tubuh, perlemakan kualitas dan kuantitas ransum serta strain yang dipelihara. Bobot karkas hasil penelitian ini dapat dikatakan sangat kecil yaitu berkisar antara 615 g/ekor- 774 g/ekor, namun nilai ini lebih tinggi dibandingkan yang diperoleh Oktavia (2013) yang menggunakan bungkil inti sawit yaitu berkisar 558 g/ekor- 662,50 g/ekor. Berdasarkan faktor yang mempengaruhi bobot karkas diatas maka dapat dikatakan bahwa bobot karkas yang kecil hasil penelitian ini dikarenakan bobot potong yang relatif rendah yaitu hanya berkisar $971 \mathrm{~g}-1109 \mathrm{~g} /$ /ekor.

\section{Pengaruh Perlakuan Terhadap Persentase Karkas}

Rataan persentase karkas ayam pedaging dapat dilihat dalam Tabel 3 . Terlihat bahwa rataan persentase karkas ayam pedaging berkisar antara 64,79\% $69,1 \%$ dari bobot hidup. Kisaran persentase karkas pada penelitian ini sejalan dengan pernyataan Salam, et al. (2013) yaitu ratarata bobot karkas ayam berkisar antara 6575\% dari bobot hidup pada waktu siap potong. Hasil analisis ragam menunjukkan bahwa perlakuan pemberian tepung limbah 
labu kuning memberikan pengaruh berbeda nyata $(\mathrm{P}<0.05) \quad$ terhadap persentase karkas. Uji lanjut beda nyata jujur (BNJ) menunjukkan bahwa perlakuan $\mathrm{R}_{0}, \mathrm{R}_{1}, \mathrm{R}_{2}$, nyata $(\mathrm{P}<0.05)$ lebih tinggi daripada $R_{3}$, namun diantara $R_{0}, R_{1}$, $\mathrm{R}_{2}$ tidakberbeda nyata $(\mathrm{P}>0.05)$ penelitian ini setara dengan nilai yang dilaporkan oleh Djunaidi,et al. (2009) berkisar $64,47 \%-70,50 \%$ untuk ayam umur 35 hari.

\section{Pengaruh Perlakuan Terhadap bagian komersil karkas.}

\section{Potongan Komersil Paha}

Rataan potongan komersil paha pada ayam pedaging dapat dilihat pada Tabel 3. Hasil analisis ragam menunjukkan bahwa perlakuan pemberian tepung limbah labu kuning memberikan pengaruh yang berbeda tidak nyata $(\mathrm{P}>0.05)$ terhadap potongan komersial paha kanan dan paha kiri.Rataan persentase potongan komersil paha kanan pada penelitian ini berkisar 14,17\% - 14,91 $\%$ dan rataan persentase potongan komersil bagian paha kiri berkisar $13.99 \%-14.98 \%$ dan jika dijumlahkan rataan persentase potongan komersil paha kanan dan kiri tersebut berkisar $28,28 \%-29,64 \%$. Kisaran persentase karkas pada penelitian ini sejalan dengan pernyataanmenurut Sari et al. (2014) bahwa nilai rataan persentase karkas broiler yang dipelihara selama 35 hari yaitu berkisar $27,14 \%$ - 28,48\%. Semakin meningkatnya persentase karkas, maka semakin tinggi persentase potongan paha yang dihasilkan. Tingginya persentase karkas yang dihasilkan akan mempengaruhi persentase bagian-bagian karkas lainnya, hal ini sesuai dengan pendapat Suswono, et al.(1992) menyatakan persentase bagian-bagian karkas berhubungan erat dengan bobot karkas, sedangkan bobot karkas dipengaruhi oleh bobot hidup.

\section{Potongan Komersil Sayap}

Rataan potongan komersil sayap pada ayam pedaging dapat dilihat pada Tabel 3. Hasil analisis ragam menunjukkan bahwa perlakuan pemberian tepung limbah labu kuning memberikan pengaruh yang berbeda tidak nyata $(\mathrm{P}>0.05)$ terhadap potongan komersil sayap kanan dan sayap kiri. Rataan persentase potongan komersil sayap kanan berkisar $5,66 \%-6,16 \%$ dan $5,49 \%-6,18$ $\%$ untuk sayap kiri dan jika dijumlahkan rataan persentase potongan komersil bagian sayap kanan dan sayap kiri berkisar $11,35 \%-12,33 \%$. Nilai ini setara dengan persentase sayap hasil penelitian Fitriawaty (2011) dengan nilai persentase sayap berkisar 11,23\%-12,98\% .

\section{Potongan Komersil Dada}

Rataan potongan komersil sayap pada ayam pedaging dapat dilihat pada 
Tabel 3. Hasil analisis ragam menunjukkan bahwa perlakuan pemberian tepung limbah labu kuning memberikanpengaruh yang berbeda sangat nyata $\quad(\mathrm{P}<0,01)$ terhadap potongan komersil dada kanan dan dada kiri. Uji BNJ pada potongan komersil bagian dada kanan menunjukkan bahwa $\mathrm{R}_{1}, \mathrm{R}_{2}, \mathrm{R}_{3}$, nyata $(\mathrm{P}<0,01)$ lebih tinggi daripada $\mathrm{R}_{0}$, namun diantara $\mathrm{R}_{1}, \mathrm{R}_{2}, \mathrm{R}_{3}$ tidak berbeda nyata $(\mathrm{P}>0,01), \quad \mathrm{Uji}$ BNJ potongan komersil bagian dada kiri menunjukkan bahwaR $_{0}, \mathrm{R}_{2}, \quad \mathrm{R}_{3}$ nyata $(\mathrm{P}<0,01)$ lebih tinggi daripada $R_{1}$, namun diantara $R_{0}, R_{2}$, $\mathrm{R}_{3}$ tidak berbeda nyata $(\mathrm{P}>0,01)$.

Rataan persentase potongan komersil dada kanan berkisar 13,01 \% $16,73 \%$ dan $14,98 \%$ - $17,73 \%$ untuk dada kiri dan jika dijumlahkan rataan persentase potongan komersil bagian dada kanan dan dada kiri berkisar 30,43\% - 33.37\%. Nilai persentase potongan komersil bagian dada kanan dan kiri tersebut saat dijumlahkan hampir setara dengan penelitian perlakuan ransum komersial terhadap ayam broiler dengan lama pemeliharaan 35 hari sebesar 31,26\%-32,26\% (Oktavia, 2013).

\section{Pengaruh Perlakuan Terhadap} Persentase Lemak Abdominal.

Rataan persentase lemak abdominal disajikan pada Tabel 3. Pada tabel tersebut terlihat bahwa persentase lemak abdominal ayam percobaan berkisar $1,35 \%$ - 2,076 dari bobot badan.
Persentase lemak abdominal tertinggi berada pada $\mathrm{R}_{2}(2,07 \%)$ dan persentase lemak abdominal paling rendah berada pada $R_{3}$ yaitu (1,35\%). Berdasarkan hasil analisis ragam menunjukkan bahwa perlakuan pemberian tepung limbah labu kuning memberikan pengaruh yang tidak berbeda nyata $(\mathrm{P}>0,05)$ terhadap persentase lemak abdominal ayam pedaging. Persentase lemak abdominal pada ayam percobaan berkisar 1,5\% $2,07 \%$.

Persentase lemak abdominal pada perlakuan terhitung normal, sesuai pendapat Lesson dan Summer (2005) bahwa persentase lemak abdominal dalam keadaan normal berkisar $1 \%-2,5 \%$ dari bobot badan. Hal ini kemungkinan dapat disebabkan oleh kandungan energi dan protein dalam ransum adalah sama sehingga tidak terjadi kelebihan energi yang berdampak pada tidak terjadinya penimbunan lemak.

\section{KESIMPULAN}

Berdasarkan hasil penelitian dapat disimpulkan bahwa, pemberian tepung limbah labu kuning(Cucurbita moschata) sebanyak $15 \%$ dalam ransum ayam pedaging memberikan pengaruh yang baik terhadap pertumbuhan bobot badan, persentase karkas, sebagian persentase potongan komersil karkas dan lemak abdominal ayam pedaging. 


\section{DAFTAR PUSTAKA}

Abbas, R.J., S.A. Alshaheen and T.I. Majeed. 2017. Evaluation of the produvtive and physiological performance of Japanese quail (Coturnix coturnix japonica) fed different level of pumpkin (Cucurbita moschata) seeds oil. International Journal Veterinary Science. 6 (1): 31-35.

Aguilar, Y.M., O.M. Yero, M.I.V. Navarro, C.A.B. Hurtado, J.A.C. López and L.B.G. Mejía. 2011. Effect of squash seed meal (Cucurbita moschata) on broiler performance, sensory meat quality, and blood lipid profile. Brazilian Journal of Poultry Science. 13 (4): 219-226.

Bona, S., S.F.G. Dillak dan H. Sutedjo. 2015. Pengaruh kombinasi tepung labu kuning (Cucurbita moschata, Durch), tepung daun kelor (Moringa oleifera, Lam)dan minyakkelapa sebagai pengganti jagung dalam ransum terhadap persentase daging, tulang dan karkas ayam broiler. Jurnal Nukleus Peternakan, 2 (1):53-58.

BPS, 2014. Data Produksi Tanman Semusim. Jakarta.

Chiroque, G, G. Vásquez, E. Vásquez, D. Más, C. Betancur, C. Ruiz, A. Botello and Y. Martínez. 2018. Growth performance, carcass traits and breast meat fatty acids profile of helmeted guinea fowls (Numida meleagris) fed increasing level of linseed (Linum usitatissimum) and pumpkin seed (Cucurbita moschata) meals. Brazilian Journal of Poultry Science. 20 (4): 665674.

Eleiwa, N.Z.H., R.O. Baker and S.A. Mohammed. 2014. Phytochemical and pharmacological screening of seeds and fruits pulp of Cucurbita moschata Duchesne cultivated in Egypt. International Journal of Pharmacognosy and Phytochemistry. 29: 2051-2058.

Djunaidi, I.H., T. Yuwanta dan M. Nurcahyanto. 2009. Performa dan bobot organ pencernaan ayam broiler yang diberi pakan limbah udang hasil fermentasi Bacillus sp. Media Peternakan. 32(3):212-219.

Fitriawaty. 2011. Pengaruh penambahan tepung daun katuk dan tepung rimpang kunyit dalam ransum terhadap persentase berat bagianbagian karkas dan organ dalam broiler. Skripsi. Universitas Hasanuddin. Makassar.

Gaafar,H.M.A., A.R. Ayat, and K.F.A and E.1 Reidy. 2014. Effect of diet supplemented with pumpkin (Cucurbita moschata) and black seed (Nigela sativa) oils on performance of rabbit: 1. Growth performance, blood hematology and carcass traits of growing rabbits. Report and Opinion 6: 5259.

Komalig, D.F., J.R. Leke, J. Laihad dan C. Sarajar. 2016. Penggunaan tepung limbah labu kuning dalam ransum terhadap penampilan produksi ayam ras petelur. Jurnal Zootek Zootek Journal. 36 (2): 342-352.

Leeson, S. and J.D. Summers. 2005. Commercial Poultry Nutrition. Third Edition, Nottingham University Press, Nottingham.

Mandey, J.S., Y.H.S. Kowel, M.N. Regar and J.R. Leke. 2017. Effect of different level of energy and crude fiber from sawdust in diets on carcass quality of broiler. Journal of the Indonesian Tropical Animal Agriculture. 42(4):240-246. DOI: 10.14710/jitaa.42.4.240-246. 
Nawirska-Olszanska, A., A. Kita, A. Biesiada, A. Sokoł-Łeztowska and A.Z. $\quad 2013$. Characteristics of antioxidant activity and composition of pumpkin seed oils in 12 cultivars. Food Chemistry. 139: 155-161.

Oktavia, I. 2013. Persentase karkas dan potongan komersial ayam broiler yang diberi pakan mengandung bungkil inti sawit dengan atau tanpa penyaringan.Skripsi. Institut Pertanian Bogor. Bogor.

Salam, S., A. Fatahilah., D. Sunarti, dan Isroli. 2013. Bobot karkas dan lemak abdominal broiler yang diberi tepung jintan hitam (Nigella sativa) dalam ransum selama musim panas. Jurnal Sains Peternakan. 11 (2): 84-89.

Salombre, F. J., M. Najoan., F. N. Sompie dan M. R. Imbar. 2018. Pengaruh penggunaan silase kulit pisang kepok (Musa paradisiaca formatypica) sebagai pengganti sebagian jagung terhadap karkas dan viscera broiler. Jurnal Zootek Zootek Journal. 38 (1): 27-36.

Sari, M. L., F. N. L. Lubis dan L. D. Jaya. 2014. Pengaruh pemberian asap cair melalui air minum terhadap kualitas karkas ayam broiler. Agripet. 1 (14): 71-75.
Steel, R. G. D dan J. H. Torrie. 1995. Prinsip dan Prosedur Statistika: Suatu Pendekatan Biometrik. Terjemahan B. Sumantri. Gramedia Pustaka Utama, Jakarta.

Subekti K., H. Abbas, and K.A. Zura. 2012. Kualitas karkas (berat karkas, persentase karkas dan lemak abdomen) ayam broiler yang diberi kombinasi C.P.O. (crude palm oil) dan vitamin $\mathrm{C}$ (ascorbic acid) dalam ransum sebagai anti stress. Jurnal Peternakan Indonesia.14 (3): 447-453.

Suswono, I., Rosidi dan E. Tugiyanti. 1992. Bagian-bagian Karkas Ayam Broiler Dibawah Pengaruh Lantai Kandang Dan Frekuensi Pemberian Pakan Yang Berbeda. Laporan Hasil Penelitian. Fakultas Peternakan Unsoed. Purwokerto.

Valdez, A. L.P and M. R Mella. 2019. Pumpkin waste as livestock feed: impact on nutrition and animal health and on quality of meat, milk,and egg. Animals. 9 (10):116.

Wafar, R.J., M.I. Hannison, U. Abdullahi and A. Makinta. 2017. Effect of pumpkin (Cucurbita pepo L.) Seed meal on the performance and carcass characteristics of broiler chickens. Asian Journal of Advances in Agricultural Research. 2(3): 1-7. 